\title{
ENVIRONMENTAL DISPLACEMENT IN MALAYSIA The Effects of the Development Process on Rural and Native Communities
}

\author{
Sahabat Alam Malaysia
}

Malaysia is a land endowed with exquisite natural beauty and plentiful natural resources. With an annual rainfall of around eighty inches and the perpetual greenery of the rainforest, Malaysia is also spared the extremities of weather conditions and natural disasters such as earthquakes, volcanic eruptions or hurricanes. The most debilitating natural phenomenon is flooding that occurs during the monsoons in the east coast of peninsular Malaysia and in some parts of East Malaysia.

In Malaysia, the Malays make up the majority of the population (sixty percent) and have mainly been agriculturalists who till the soil to grow fruit trees, rice and other crops. Chinese and Indians, brought in during the colonial period, originally laboured in the tin mines and in plantations.

\section{Respect for Land}

Human beings through the ages regarded the land as a source of their sustenance, a renewable resource to be cultivated, reaped and nurtured. Land has been regarded as a source of livelihood as well as a traditional heritage to be passed down from generation to generation. Those that fed from the land learned to respect and worship it. People learned to return to the earth what had been taken from it. We can recognize this reverence in cultures of the indigenous people and natives of all the continents.

In recent times, land began to acquire a new worth. No more did humanity accord it the reverence and mysticism as did their predecessors, or to regard the earth as a source of

Sahabat Alam Malaysia (Friends of the Earth) is a Malaysian Environmental NGO rejuvenation, a sustainable cycle that allows them to reap from it but yet requires their constant nurturing. Land began to be regarded as a commodity. Its value in monetary terms began to be coveted. With the increasing sophistication of theeconomy, the business of making money became the order of the day. Land was increasingly viewed as a good investment and something to be used for development.

In cities and towns, land began to be more and more utilised for housing, commercial and industrial uses. With this centralisation of facilities, business investments - both local and foreign increased, while services and other facilities were upgraded. Increased sophistication and material success of the residents resulted in demand for better housing, shopping centres, recreational and entertainment amenities, etc. All this required land space and land became not only a commodity for development but also for speculation. The price of houses, factories and commercial buildings began to escalate and those with money to spare found investments to be made in real estate, a profitable enterprise. The price of property in Malaysia was still relatively low compared to other countries in East Asia, but then there was a speculative trend and rush by foreigners, especially from Singapore, Hong Kong, Taiwan and Japan, to buy up available land in Malaysia. This led to escalating property values, making housingless affordable for the locals. The government's policy of encouraging industrialization and achieving the status of a "developed country" by the year 2020 has also meant pressure for further land development and increased the demand for land in outlying areas that were previously reserved for agriculture and plantations.

As the country concentrates more on manufacturing and production ventures, the need for expansion is inevitable and more and more agricultural land is slowly being converted for housing and industrial projects. Reports in local papers confirm such trends:

- Plantation companies will benefit from expected increases in the value of agricultural land following the increased demand for industrial land in the Klang Valley.

- Plantation owners have converted their agricultural lands for residential purposes.

- All industrial land sold out in Selangor. Tan Sri Muhammad Taib would not allow factories to be built on former agricultural lands.

- Industrial land to cost more in Klang Valley in 1990.

- Malacca, running short of land, will be offered to foreign companies flocking to invest there.

- Syndicates acquire property for speculation in Gelang Patah, Johore, near the site of the second link to Singapore.

- Reclamation project of the Perlis coast for a free trade zone will start soon.

- Pahang will open more land for industrial sites.

Thus, we can see how land is no longer viewed as a resource to be nurtured and respected, but as a commodity for exploitation and rape. Agrarian policies are regarded as a retardation to growth unless done on a large scale, while industrialisation is favoured. In decisions about land use, first priority is mainly given to economic profitability; i.e., profit maximization is the basis for decision-making. 


\section{Erosion of Values}

With the erosion of values that we have for the land, land used for small holdings, small-scale agriculture, land left fallow for regeneration, forests left untouched in their pristine state and undeveloped lands are now regarded as being underutilised.

The eagerness to profit from the environment takes many forms:

- Mining the land for natural resources such as tin, oil and coal;

- Stripping forests of valuable timber;

- Draining and cutting mangrove areas for aquaculture;

- Megaproject development of beautiful unspoiled beaches; islands and hill resorts to bring in tourist dollars; and

- Large-scale plantations and industrial estate development.

Choice lands are being developed by big corporations and large sections of real estate are being bought up by rich foreign speculators. This has resulted in the shift of land ownership from the bulk of the population to export orientated foreigners and the local elite. The bulk of the population, especially the poor and indigenous people, suffer the consequences of such "progress."

The rapid modernisation and neglect of ecological principles during the past two decades has led to the creation of poverty and new under- privileged groups. The poor communities like farmers, fishermen, natives living in the forests and estate workers, suffer the loss or deterioration of their resources (soil, land, water and forests) on which their livelihood and well-being depend.

Major causes of poverty and environmental displacement of persons can be traced to these factors:

- Logging of forests that affect farmlands and forest resources of villagers living near forest areas including the indigenous people of Sabah and Sarawak, and rural communities in Peninsular Malaysia;

- Silting of rivers due to deforestation, hill cutting, housing or construction projects, resulting in the increased incidence and severity of floods in rural as well as urban areas. This human-made disaster has caused damage in the millions of dollars to crops, houses and property;

- Development of large-scale projects, such as highways, dams, buildings and tourist projects, have brought about evictions and displacement of those living in the vicinity;

- State acquisition or landowners' repossession of rich farmlands create a loss of livelihood and displace farmers. The recent proposal to amend the Land Acquisition Act 1960 makes it easier for the government to acquire land for development without having to be challenged in a court of law, and may further aggravate the issue of internally displaced persons.

- Pollution of rivers and seas, destructive methods of fishing, trawlers and depleted fishery resources reduced fish catches and the incomes of fishermen. Fishermen have been watching their daily catches gradually decrease as rivers and seas become more and more polluted.

The encroachment upon their fishing waters by large trawlers, with their destructive methods of fishing, further reduces the fishery resources. The livelihood of 3,000 fishermen in Kuala Muda, Kedah, is threatened by the influx of aquaculture projects into the area. Thousands of acres of rich mangrove forests have been cleared for fish and shrimp cultivation. This destruction has resulted in river pollution and a disturbance to the delicate mangrove ecosystem leading to a drastic drop in river resources such as fish, prawns, crabs and shellfish. Kuala Muda is not the only place to be affected by the negative impacts of aquaculture projects; other states - Selangor, Perak, Johore, etc. - have also experienced such adverse results.

The fishermen have found their daily income decrease from U.S. $\$ 30.00$ to $\$ 5.00$ a day. They are finding it extremely hard to support their families on such a meagre income. They say that their problems arose with the advent of the aquaculture projects.

\section{Development, Dlsplacement, Degradation}

As plantations in outlying city centres are converted to housing and industrial estates, we find groups of estate workers being displaced. Even though estate conditions are terrible, workers are at least given a house on the estate premises and a typical estate will provide other facilities, such as a school, a recreation hall, a playing field, a temple, a grocery co-operative or shop and dispensary for

"No more did humanity
accord it the reverence and
mysticism as did their
predecessors, or to regard the
earth as a source of
rejuvenation, a sustainable
cycle that allows them to reap
from it but yet requires their
constant nurturing. Land
began to be regarded as a
commodity."

basic medicines. Whole communities exist in the estates; when plantation displacement occurs, the lives of these communities are disrupted.

In 1969, the Bukit Jelutong Plantations had to make way for the new township of Shah Alam. The workers were removed and some went their separate ways. However, a majority of them built squatter settlements near the railway tracks and found work as contract or factory labourers. They were promised low-cost housing and other retrenchment benefits, which many of them did not receive. Finally, after 20 years of waiting and living in squalid conditions, some families were allocated low-cost homes or empty land on which to build.

Recently, the government announced that estate lands in the Klang Valley will be converted for industrial and other development projects. This will result in the displacement and loss of 
jobs for more than 35,000 estate workers. Many of the young and strong labourers may be able to work in the factories, but for the older ones who have lived and worked for most of their lives in estates, adjusting to life outside the estates without a job, home or future prospects will be extremely difficult and dismal.

Not only are plantations affected by urban renewal programs, but farmlands in and around cities are also not spared by progress. In Penang, 73 acres of rich fruit-farming land in Kampong Pondok Upeh was acquired by the state government in 1973, despite fervent protests from farmers, to make way for the Balik Pulau-Relau road. The Thean TeikEstate dispute between alandowner and 12,000 residents, who faced eviction from their rich farmlands, culminated in the death of an innocent woman. The residents, who had been farming on this fertile, agricultural land for generations, face dislocation because the ownerwants to turn the land into a township.

Squatters in settlements in the Sungai Buloh forests, who had previously been displaced from Kampong Sungai Damansara, face the daunting prospect of being relocated once again. Though their present longhouses are dismal and withoutbasic amenities, they do not enjoy being moved around with no promise of permanent homes. They feel that their rights are being disregarded. They tell of an instance where the developer had dumped sand residues into a pond that the residents had dug themselves for rearing fish. The government, they say, has plans for golf courses and parks but no alternative housing for them.

Squatters in Kampong Bukit Sungai Putih in Selangor had built decent homes around the hilly region, blending in perfectly with nature. Their idyllic existence was destroyed one day in February this year when the demolition squad from the district office came and tore down their homes because they were squatters.

Large-scale tourism is another factor that brings about major changes in the lives of the natives and rural Malaysians. Redang Island, site of one of the most beautiful marine ecosystems in the world, is in the process of being developed for tourism. Golf courses, five-star hotels and condominiums are presently being constructed. The fishermen's village at the edge of the island, which houses around 300 families, is to be relocated further inland to make way for the development project. Limited water resources on the Island will be further strained when water is channelled to green the golf course and to fill the needs of the hotels and condominiums. Hill clearings have disrupted small streams, accelerated soil

\section{"Large-scale tourism is another factor that brings about major changes in the lives of the natives and rural Malaysians. Redang Island, site of one of the most beautiful marine ecosystems in the world, is in the process of being developed for tourism."}

erosion and caused silting in the river. These infractions will definitely affect the well-being of the villagers.

On Langkawi Island, physical development to cater to the tourism industry, has destroyed catchment areas and small streams, drastically reducing the water resources of the island. This has resulted in crop failure and flooding during the rainy seasons. Destruction of Gunung Raya, a major catchment area, has caused farmers in the lowlands to suffer the effects of massive soil erosion, sedimentation and slope failure. Vested interests in developing Langkawi as a major tourist destination have put pressure on landowners to dispose of their lands. Due to persuasion or intimidation, many locals have reluctantly sold their lands, their heritage. At Pantai Kok in Langkawi, enterprising islanders had built quaint chalets and rented them out to tourists. Their thriving business received a blow when they were informed that the state government had given the area to a French company to be developed.

Unsound agricultural projects have also brought hardships to farmers involved in government padi-growing schemes. In Sungai Manik and Kerian, the Integrated Agriculture Development Project failed because of irrigation problems. Serious flaws in the irrigation schemes implemented made farmers doubt the effectiveness of the project. In Kampong Bagan Hulu, the digging of two nearby rivers by the Malaysian Fisheries Development Board to breed prawns and fish has disrupted the water flow and led to the flooding of padi fields with salty water, especially during a storm or high tide. This calamity destroyed their crops and jeopardised their main source of income. Lamented one Lebai Talib Ali, a wizened hundredyear old man,

I personally cleared and cultivated the land during the pre-Merdeka period [pre-independence period]. It took four years of toil to turn this barren earth into sustainable land for farming. Our padi, sugar-cane, corn and coconut trees which we depend on for a living, are all gone now.

\section{Disruption of Indigenous Communitles}

Finally, we come to the true environmental refugees of our region the natives or indigenous people. The Orang Asli, endemic to peninsular Malaysia, have traditionally lived in or near forests and have gathered all their nutritional requirements and basic needs from the forests. They hunted as well as collected rattan, bamboo and bertam palms to build their houses and relied on a nearby river, which was often clean and clear, for drinking and washing purposes. They also earned some money by selling jungle products and fruits collected from the forests. However, the Orang Asli have been unable to preserve this lifestyle free from external pressures.

The construction of the Simpang Pulai Pos Slim Highway to take tourists to the proposed mega-tourist project on 
the Kinta Highland in Perak has affected the environment and brought great hardship to the Orang Asli living in the vicinity. The communities have been dwelling there for many generations. Six Orang Asli villages along the Sungai Raia rely on the river for their water and fish supply. They also cultivate padi, tapioca, keledek, corn, medicinal plants, fruit trees, chili and pepper. From the forests, they collect rattan, bamboo, mengkuang leaves and tree bark resins. Commercial logging and highway construction have depleted the forests' natural resources and destroyed large tracts of land cultivated with cash crops. Their crystal-clear river has been muddied and silted. Now, the natives of some of the villages have to walk a mile to collect drinking water. There was blatant disregard for the possible impact the road construction would have on the Orang Asli living in the area. Such encroachments on their environment have brought poverty, hunger and illhealth to these people.

The love and respect for their land is expressed by an elder of one of the villages:

When we lose our land we are forced to move up into the hills. We know that those uplands are the vital source of water besides being burial grounds of our ancestors. Do you want us to drink the blood of our ancestors? Our newborn babies are raised on the water originating from the hills and, if polluted, they will get sick and die. If the air gets contaminated, it will affect the water and we will all get sick!

The government's decision to build a second international airport at Sepang in Selangor is causing the Orang Asli in that region much anxiety over their future. The Orang Asli are quite happy with their present living conditions in the district and have no wish to move. They had been forced to move from their original settlement during the Second World War and yet again during the Communist insurgency. They object to being moved around like excess baggage, indignantly declaring, "We are not nomads!"

In Johore, the Linggiu dam project to supply water to neighbouring Singapore will affect the livelihood of 300 Orang

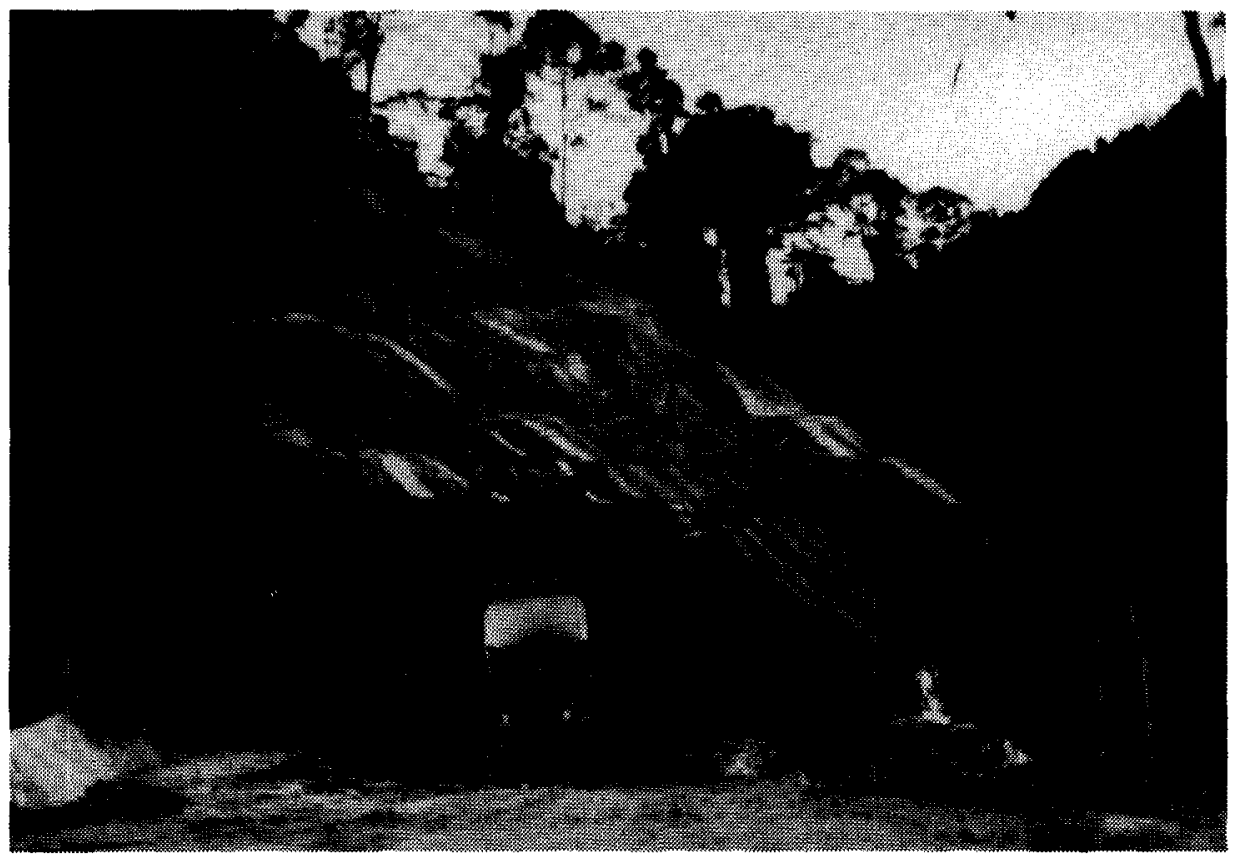

PHOTO:SAHABAT ALAM

Fig. 1: Home to the Orang Asli Tribe, this Malaysian forest is being cleared for a highway

Asli in the Ulu Sungai Linggiu, Kampong Pasir Assam, Kampong Semengor and Kampong Sayong Pinang areas. Construction of the dam will destroy valuable forests, and many animals and birds will perish from loss of habitat. When the dam is completed, 5000 hectares will be submerged underwater and another 14614 hectares will be set aside as water catchment areas. The natives' fruit orchards, hunting grounds and forest resources will all be submerged or, if located in catchment areas, they will notbe allowed free access. The remaining forest lands will be taken up by government land development schemes, leaving nothing for the Orang Asli. "Everything needs to live, be it the elephant or ants or trees or tigers or the fish in the rivers and us too, the Orang Asli," said an Orang Asli medicine man, Abdul Rahman.
The Batang Ai power project in Sarawak was constructed in the heartland of the Iban tradition and culture. The project covered some 40,000 acres of land, of which 21,000 acres were eventually flooded, destroying large areas of forests and lands held under customary tenure, which include swidden farms, crops and ancestral lands. The project involved the resettlement of about 3,000 people. The resettled Iban natives face many problems and say that they had been treated unfairly. Instead of the eleven acres of cleared land that they said they had been promised, each family only received one acre. It also turned out that they had to pay for their new longhouses when they were informed earlier that they would be free. While some families received cash compensation, they did not know how to deal with their newfound wealth and squandered it away. 
Most families were in shock over thenew system and new way of living; many could not cope.

At Bukit Peninjau, Sarawak natives were encouraged to move from their lands which were converted into plantations. Relocated in nearby settlements, these Ibans were recruited to work on the plantations. They were attracted by promises of being given free land and housing after ten years of

\section{"Unrestricted development in a country anxious to progress and achieve the status of a newly developed nation has caused environmental degradation, which has brought on poverty, displacement and the uprooting of communities faced with an uncertain future."}

service as well as schools and medical services, etc. The lbans found that they were settled in small, single-family homesteads dispersed within the estate, very much different from life in the longhouses. To their dismay, they also found that they had to pay rent for their "free" housing. They experienced problems with their water supply and medical facilities. They had to spend a lot on travelling expenses to distant hospitals. Workers who became ill, were injured during work, or who retired, were not compensated or paid wages. Schools were provided but no church, despite the fact that most Ibans are Christians. Ten years of waiting passed and they were not given any free land to cultivate crops. After a trail of broken promises, when Sime Darby took over the plantations and wanted to make massive cuts in their pay, the natives went on strike. When police intimidation failed, the management sought to evict the workers and brought in labourers from Kalimantan.

\section{The Penans of Sarawak}

The most well-known Sarawak tribe today must be the Penans, who gained international recognition for theirwidely publicised barricades against loggers in an attempt to protect the destruction of their traditional lands, the rainforests, where they have lived, hunted and survived since time immemorial. Peaceloving, gentle people, it has been said that a Penan would rather shoot his blowpipe at a tree than aim it at his aggressor. With the advent of logging, the Penans began to suffer its consequences: polluted rivers, decreased wildlife, game and fish and depleted forest resources. The community experienced a drop in the quality of living and health. They brought their complaints to the government authorities but nothing was done. Finally, when they had exhausted all avenues in trying to protect the destruction of the forests and their very survival, they decided to blockade the logging roads that went through their customary lands. The subsequent arrests evoked worldwide public sympathy for these forest people.

A recent proposal for a Penan Biosphere Reserve at Malana Protected Forests in Ulu Baram was opposed by the Penans because the area had been logged and the land was barren and depleted of resourcessuch as wildlife, fish and jungle produce so vital to the survival of the tribe. Some Penans feel that they should be given land in an untouched, virgin forest as a biosphere reserve, if the government really cared about their welfare.

These are the harsh realities of life for the poor, rural and indigenous communities who try hard to eke out a living directly from the land and waters. Unrestricted development in a country anxious to progress and achieve the status of a newly developed nation has caused environmental degradation, which has brought on poverty, displacement and the uprooting of communities faced with an uncertain future. Farmers, fishermen and indigenous people are losing access to the natural resources of Malaysia which are slowly, but surely, coming under the control of a few.
One final comment must be directed at the First World nations with their strong network of world banking systems, multinational corporations and large scale agricultural policies; they are the initial purveyors of policies that encourage environmental destruction. Aggressive promotion of grandiose schemes and moneymaking ideas enthusiastically embraced by Third World elites, eager for a share in the spoils, sets the process of environmental degradation in motion. As long as economic growth remains the main indicator of gauging a country's progress or growth, the environment, and those that depend on it for their livelihood, will always be affected.

The suffering and misery brought about by environmental degradation is here expressed in the words of a young Sarawak native:
For ages, our people have been collecting gaharu and rattan to be exchanged for money. Now the timber companies have entered and logged the forest. We don't have any money as our source of income is gone. Our food comes from the forest; the different types of sago are our staple diet are now gone too. We the Penan do not have farms. If the forest is gone, we don't have food. How are we to survive? When we travel through the forests, we don't carry heavy loads, as whatever food and utensils [we need] are found in the forest. But not now. Gone. Everything is gone.

Nevertheless, native communities are looking ahead and working to shape a better future for the coming generations. During the largest ever native gathering in Sarawak in 1989, a resolution was drafted which declares: "We are not against development when we refuse to move out of our land and forests, but we are against theft of our land, our rights and cultural identity. It is our right to decide what kind of development we want and to develop at our own pace."

\section{References}

Much of the material for this article was drawn from: Pernloigah: Orang Asli News (Centre for Orang Asli Concerns); Evelyne Hong, Natives of Sarawak; Utusan Konsumer (19901991); New Straits Times, Kuala Lumpur; The Star, Kuala Lumpur; Malay Mail, Kuala Lumpur. 